\title{
Plutonium fluxes from the Rhône River to the Mediterranean Sea
}

\author{
F. Eyrolle, M. Amaud ${ }^{1}$, C. Duffa and P. Renaud \\ Institut de Protection et de Süreté Nucléaire, Département de Protection \\ de l'EnvironnementSERNAT, CEN-Cadarache, BP. 1 , \\ 13108 Saint-Paul-lez-Durance cedex, France \\ ${ }^{1}$ Institut de Protection et de Súreté Nucléaire, Département de Protection \\ de l'EnvironnementSSERNAT, Base IFREMER, BP. 330, \\ 83507 La Seyne-sur-Mer cedex, France
}

\begin{abstract}
Plutonium isotopes carried by the Rhone River mainly come from the catchment basin weathering affected by atmospheric fall-out and from the liquid effluent discharges from the fuel reprocessing plant located at Marcoule. Nowadays, while ${ }^{233} \mathrm{Pu}$ industrial inputs are still at least ten times higher than terrestrial inputs, ${ }^{209+240} \mathrm{Pu}$ inputs from industrial and terrestrial source terms are of similar importance, i.e. I GBq $y^{-1}$ each. An empirical relation between the ${ }^{239+240}$ Pu activities in the river water downstream Marcoule and the Rhone flow rate is obtained from data collected over the 1987-1998 period. This relation underlines that the river bed sediments act as a delayed source of plutonium depending on the bydrological conditions of the river. During flood events this delayed source may contribute up to $40 \%$ of the plutonium activity at the lower course of the Rhône River. Furthermore over the 1987-1998 period the accumulated ${ }^{239+240} \mathrm{Pu}$ and ${ }^{235} \mathrm{Pu}$ activities within the whole sedimentary compartment of the river or depasited on the terestrial surroundings during flood events arc 15 and $4 \mathrm{GBq}$ respectively, thus representing about $10 \%$ of inputs. At present, this stock that can potentially be re-suspended, is an important ${ }^{239+240} \mathrm{Pu}$ source term at the scale of the Rhône River catchment basin.
\end{abstract}

\section{INTRODUCTION}

Plutonium nuclides reach the Rhône River system through the weathering of surface soils contaminated by the global fallout from atmospheric nuclear tests, and through the liquid effluent discharges from the Marcoule nuclear fuel reprocessing plant.

The Rhône River catchment basin is $98845 \mathrm{~km}^{2}$ large, and has a $5210^{9} \mathrm{~m}^{3}$ annual liquid flow carrying from 2 to $2010^{6}$ tons of solid matters towards the Mediterranean Sea [1-5]. The Rhône River is $812 \mathrm{~km}$ long, among which 200 are in Switzerland. At its lower course and just upstream from the city of Arles it divides into two branches, the Grand Rhône and the Petit Rhône, which flow across a large Delta, the Camargue. The former branch drains $90 \%$ of the water discharge. The Rhone River is the most important river flowing to the Occidental Mediterranean Sea.

The whole set of radionuclides introduced into the Rhône River catchment basin will be partly exported to the Mediterranean Sea. Nevertheless the radionuclide transportation phenomena and residence time as well as fluxes and exportation kinetics within the river are only partially known [6]. ${ }^{239+240} \mathrm{Pu}$ and ${ }^{238} \mathrm{Pu}$ activities in particulate phase were measured in the Grand Rhône at Arles between 1987 and 1998. The very last part of the river mixes all the radionuclides inputs received by the catchment basin. The analysis of these data allows then to qualify and to quantify the radionuclides exportation fluxes from the Rhône River to the Mediterranean Sea giving boundary conditions and parameters to their transfer models.

\section{PU SAMPLING AND ANALYSES}

From 1997 to 1998 , water samplings were performed on the Grand Rhône, at the level of Arles (Figure 1). 100 to 2501 of non filtered and filtered $(<450 \mathrm{~nm})$ samples were analysed for ${ }^{238} \mathrm{Pu}$ and ${ }^{239+240} \mathrm{Pu}$ content after co-precipitation with $\mathrm{Fe}(\mathrm{OH})_{3}$ as described in [7] and using radiochemical procedures by solvent extraction and/or cation exchange. Upon radiochemical separation, plutonium 
alpha sources were preparated by electrolytic plating onto stainless-steel discs. Two distinct tracers were required to quantify the recovery of plutonium isotopes extractions first by co-precipitation then by the radiochemical steps. The determination of $\mathrm{Pu}$ isotopes activities was achieved as described in [8].

The plutonium activities in the particulate phase, calculated by subtracting the activity measured in filtered samples from the activity found in unfiltered samples, are reported in table $\mathrm{I}$. The speciation of plutonium between the dissolved and particulate phases is discussed elsewhere $[9,10]$. The SPM concentrations were measured by standard gravimetry. The Rhône River National Company recorded the Rhône River flow rates in Arles. Complementary data covering the 1987-1994 period were taken from the literature [11] (table 1).

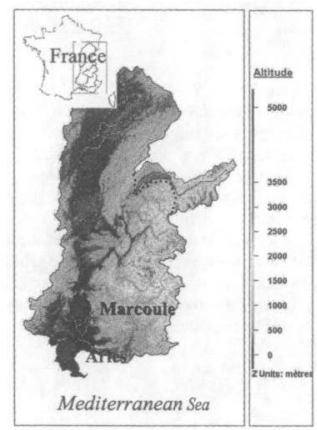

Figure 1: The Rhòne river catchment basin.

Table 1: ${ }^{239+240} \mathrm{Pu}$ and ${ }^{238} \mathrm{Pu}$ activities in the Rhône River, SPM at Arles between 1987 and 1998 , flow rates at $\mathrm{Arles}$ and ${ }^{238} \mathrm{Pu}$ ${ }^{239+240}$ Pu Activity Ratio (AR).

\begin{tabular}{|c|c|c|c|c|c|}
\hline Sampling date & $\begin{array}{c}\text { Flow rate } \\
\left(\mathrm{m}^{3} \mathrm{~s}^{-1}\right)\end{array}$ & $\begin{array}{c}\text { SPM } \\
\left(\mathrm{mg} \mathrm{I}^{-1}\right)\end{array}$ & $\begin{array}{c}{ }^{238} \mathrm{Pu} \\
\left(\mathrm{mBq}^{-1}\right)\end{array}$ & $\begin{array}{l}{ }^{239+240} \mathrm{Pu} \\
\left(\mathrm{mBq} \mathrm{g}^{-1}\right)\end{array}$ & RA \\
\hline $02 / 07 / 1987[11]$ & 2989 & 11,7 & 2,68 & 9,42 & 0,29 \\
\hline $03 / 07 / 1987[11]$ & 3005 & 43,0 & 2,56 & 9,87 & 0,26 \\
\hline $04 / 07 / 1987[11]$ & 2636 & 124,0 & 1,22 & 4,22 & 0,29 \\
\hline $05 / 07 / 987[11]$ & 2352 & 715,0 & 0,18 & 0,78 & 0,23 \\
\hline $10 / 03 / 1991[11]$ & 4554 & 1777,0 & 0,07 & 0,36 & 0,19 \\
\hline $12 / 03 / 1991[11]$ & 2985 & 112,0 & 0,34 & 1,4 & 0,24 \\
\hline $18 / 03 / 1991[11]$ & 1718 & 28,6 & 0,46 & 2,19 & $0,2 \mathbf{i}$ \\
\hline 11/05/1994[11] & 1925 & 38,1 & 0,06 & 0,18 & 0,33 \\
\hline $07 / 06 / 1994[11]$ & 1873 & 37,2 & 0,04 & 0,23 & 0,17 \\
\hline $09 / 08 / 1994[11]$ & 1016 & 12,6 & 0,62 & 1,67 & 0,37 \\
\hline $02 / 11 / 1994[11]$ & 1700 & 17,0 & 0,75 & 2,07 & 0,36 \\
\hline $06 / 11 / 1994[11]$ & 8865 & 3600 & 0,03 & 0,17 & 0,18 \\
\hline $13 / 05 / 1997[9]$ & 1800 & 31,2 & 0,57 & 1,40 & 0,41 \\
\hline $14 / 09 / 1997[9]$ & 1230 & 16,9 & 0,65 & 1,84 & 0,35 \\
\hline $18 / 11 / 1998$ & 1872 & 35,9 & 0,12 & $0, \overline{4 l}$ & 0,29 \\
\hline $19 / 11 / 1998$ & 1846 & 39,5 & 0,11 & 0,33 & 0,33 \\
\hline $23 / 11 / 1998$ & 1203 & 15,0 & 0,15 & 0,48 & $0,3 \overline{1}$ \\
\hline
\end{tabular}




\section{RESULTS \& DISCUSSION}

Before 1992, the ${ }^{239+240} \mathrm{Pu}$ and ${ }^{238} \mathrm{Pu}$ source term within the Rhône River was mainly liquid effluents from the Marcoule complex as ${ }^{239+240} \mathrm{Pu}$ and ${ }^{238} \mathrm{Pu}$ annual inputs of industrial origin were 50 and 500 times bigher than terrigenous ones, respectively (Figure 2). At present, while the major ${ }^{238} \mathrm{Pu}$ source term is still linked to the liquid effluents from the Marcoule facility, ${ }^{239+240} \mathbf{P u}$ annual inputs related to the Marcoule installation and to the weathering of the catchment basin are of the same order of magnitude, i.e. of about $1 \mathrm{GBq} \mathrm{y}^{-1}$. In 1990 a change in the liquid effluent treatment process within the Marcoule reprocessing plant led to reduce on a 3-year period by more than a factor 10 the ${ }^{238} \mathrm{Pu}$ and ${ }^{239+240} \mathrm{Pu}$ annual releases. Furthermore, in December 1997, the Marcoule fuel reprocessing plant was shut down and is now being dismantled. Nevertheless, the end of reprocessing operations does not have reduced the plutonium isotopes discharged activities yet as washing effluents are produced and released.

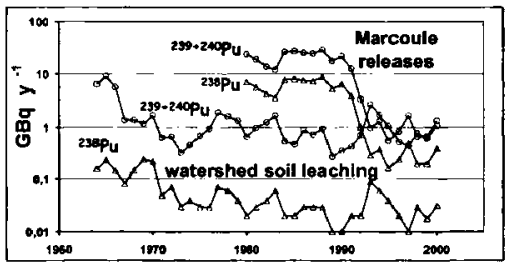

Figure 2: Historical account of ${ }^{238} \mathrm{Pu}$ and ${ }^{239+240} \mathrm{Pu}$ inputs by industrial [12] and terrigenous [13,14] source terms in the Rhône River, given in $\mathrm{GBq} \mathrm{y}^{-1}$. For industrial releases, ${ }^{238} \mathrm{Pu}$ activities are calculated from ${ }^{259+240} \mathrm{Pu}$ activities and a theoretical AR of 0.3 .

${ }^{239+240} \mathrm{Pu}$ activities measured in the particulate phase of the Rhône River fresh waters at Arles between 1987 and 1998 are reported on the Figure 3a and 3b. In an aquatic continental environment, plutonium shows a great affinity for particles and especially for particulate organic compounds and iron hydroxides and in the Rhône River it is mainly transferred in the particulate phase [9, 13]. From 1987 to 1998 , activities observed in the particulate phase were reduced by a factor 50 i.e. a factor similar to the one found for the releases from the Marcoule complex over the same period of time, excepted for the Rhône River flood periods.

The Rhône river floods induce an increase in ${ }^{239+240} \mathrm{Pu}$ activities in the River fresh waters. As a matter of fact during the 1994 large flood episodes, ${ }^{239+240} \mathrm{Pu}$ activities in particulate phase were multiplied by a factor 20 compared to the activities observed the previous days when the river flow conditions were almost those of the mean annual flow, $1700 \mathrm{~m}^{3} \mathrm{~s}^{-1}$. Thus during the 1994 great floods, ${ }^{239+240} \mathrm{Pu}$ concentrations reached the same levels that could be observed at the end of the eighties, before the decrease in Marcoule discharges.

In order to underline the evolution of ${ }^{239+240} \mathrm{Pu}$ activities into the Rhone River waters with regards to the hydraulic flow, the ${ }^{239+240} \mathrm{Pu}$ activities measured from 1987 to 1998 have been normalised with respect to the annual discharges from the Marcoule plant to take into account the source term temporal diminution. The results evince an exponential relationship between the ${ }^{239+240} \mathrm{Pu}$ activity in particulate phase at Arles and the river hydraulic flow.

For a given year, the ${ }^{239+240} \mathrm{Pu}$ activity in particulate phase $\left(\mathrm{C}_{\mathrm{y}}\right.$, in $\left.\mathrm{mBq} \mathrm{\textrm {m } ^ { - 3 }}\right)$ at Arles, can be represented by the mathematical relation [1].

$$
C_{y}=0,006 M_{y} e^{0,0004 Q} \quad\left(n=17, r^{2}=0,61\right)
$$


With $\mathrm{M}_{\mathrm{y}},{ }^{239+240} \mathrm{Pu}$ annual releases from Marcoule given in $\mathrm{MBq} \mathrm{y}^{-\mathrm{t}}$ and $\mathrm{Q}$, the River hydraulic flow given in $\mathrm{m}^{3} \mathrm{~s}^{-1}$.

Relation \{1\} could also allow understanding the impact of a plutonium accidental liquid release on the radiological quality of the river. The extrapolation to other artificial radionuclides is yet limited since the transfer of an element through the particulate phase depends on its own affinity with the suspended solid matters.
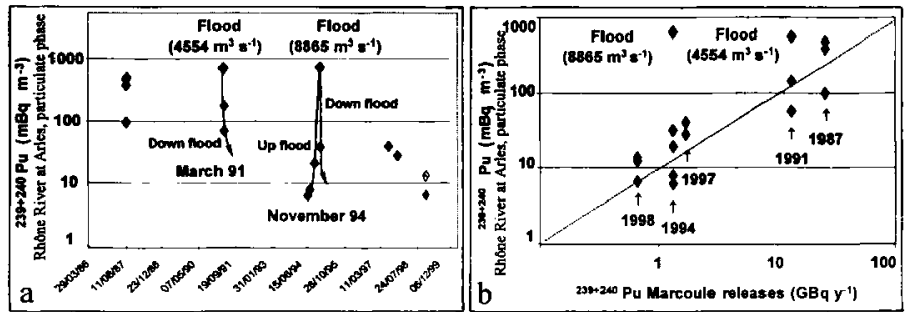

Figure 3: a- ${ }^{239+200} \mathrm{Pu}$ activities in particulate phase in the Rhône river at Arles between 1987 and 1998 (in $\mathrm{mBq}^{-3}$ ). b${ }^{23}+240 \mathrm{Pu}$ activities in particulate phase in the Rhone River at Arles between 1987 and 1998 (in $\mathrm{mBq}^{-3}$ ) nomalised to ${ }^{239+240} \mathrm{Pu}$ (in $\mathrm{GBq} \mathrm{y}^{-1}$ ) quantities released by the Marcoule reprocessing plant during the year of sampling. 1987: $\mathrm{dm}=2746 \pm$ $310 \mathrm{~m}^{3} \mathrm{~s}^{-1} ; 1991: \mathrm{dm}=2350 \pm 900 \mathrm{~m}^{3} \mathrm{~s}^{-1} ; 1994: \mathrm{dm}=1630 \pm 420 \mathrm{~m}^{3} \mathrm{~s}^{-1} ; 1997: \mathrm{dm}=1520 \pm 400 \mathrm{~m}^{3} \mathrm{~s}^{+1} ; 1998: \mathrm{dm}=1640 \pm$ $380 \mathrm{~m}^{3} \mathrm{~s}^{-1}$; with $\mathrm{dm}=$ average flow associated to data (except flood periods).

The plutonium activity increase under flood conditions is linked to a solid matters input originating either from the weathering of the catchment basin or from the re-suspension of some of the river sediments.

${ }^{238} \mathrm{Pu}$ and ${ }^{239+240} \mathrm{Pu}$ atmospheric fall-out have led to depositions characterized by ${ }^{238} \mathrm{Pu} /{ }^{239+240} \mathrm{Pu}$ Activity Ratio (AR) bordering 0.03 . Constant theoretical AR of 0.3 characterizes the liquid effluents discharged by the Marcoule installation. AR evolution when in the particulate phase measured in relation to $Q$ in the Rhône River waters at Arles, allows estimating the contribution of these two sources. The dilution of the Marcoule releases with the waters from the Rhône River catchment basin leads to obtain the theoretical dilution curve (Figure 4). AR varies from $0.37 \pm 0,12$ to $0,17 \pm 0,05$ for flows varying respectively from 1000 to $9000 \mathrm{~m}^{3} \mathrm{~s}^{-1}$ and in a general way is greater than the theoretical activity ratios. These results demonstrate the action of a delayed secondary source labelled by the releases from Marcoule and dependent upon the River hydraulic flow. This delayed source is to be put in relation with the re-suspension of sedimentary stocks accumulated within the Rhône River, downstream the Marcoule complex in quiet hydrodynamic areas and/or periods.

The dispersion of the dots (Figure 4) is partly linked to the origin of data. As a matter of fact the data have been acquired on a relatively long time scale during which activity of the sedimentary stocks were not constant since the liquid effluents from the Marcoule complex have changed with time. 


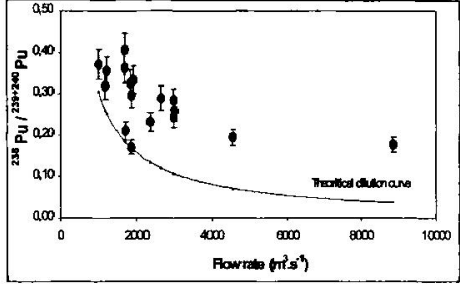

Figure 4: ${ }^{238} \mathrm{Pu} /{ }^{239+240} \mathrm{Pu}$ activity ratio measured in the Rhône river at Arles in terms of the Rhône River hydraulic flow. Equation of the theoretical dilution curve: $\mathrm{A}=232 \mathrm{Q}^{-0.96}$.

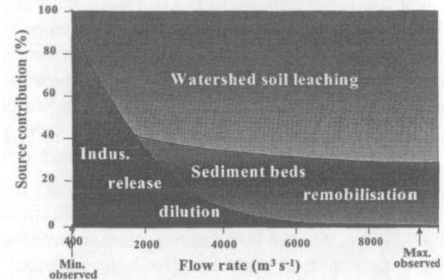

Figure 5: Schematic representation of Plutonium isotopes inputs into the Rhône river downstream the Marcoule releases, in terms of the hydraulic flow.

These observations allow schematising the contribution of the various source terms involved in the Rhône River catchment basin in relation to the hydraulic flow of the river (Figure 5). During the River flood periods, the major source terms are the catchment basin weathering and the re-suspension of the River sedimentary stocks, the latter representing up to $40 \%$ of the exported radioactivity.

In order to estimate both the plutonium isotopes fluxes and exportation status performed by the Rhône River, the empirical relation [1] was applied for the years 1987 to 1998. The results obtained underline a $73 \%$ exportation representing $82.5 \mathrm{GBq}$ of ${ }^{239+240} \mathrm{Pu}$ in the particulate phase. If we consider that $20 \%$ of the plutonium are present in dissolved phase then the overall quantity (dissolved+particular) of ${ }^{239+240} \mathrm{Pu}$ transferred at Arles can be assumed to be $99 \mathrm{GBq}$. Furthermore the Petit Rhône River located upstream Arles derives approximately $10 \%$ of the fluxes. Thus on the studied time scale, the overall quantity of ${ }^{239+240} \mathrm{Pu}$ exported towards the sea by the Rhone River system is about $109 \mathrm{GBq}$. The calculated quantity for ${ }^{238} \mathrm{Pu}$ is $30 \mathrm{GBq}$.

From 1987 to 1998 , the Marcoule ${ }^{239+240} \mathrm{Pu}$ and ${ }^{238} \mathrm{Pu}$ inputs represent 113 and $34 \mathrm{GBq}$, respectively. During the same period, the catchment basin contribution in ${ }^{239+240} \mathrm{Pu}$ and ${ }^{238} \mathrm{P} \downarrow$ is estimated to a 10.5 and $0.3 \mathrm{GBq}$, respectively. Thus the ${ }^{239+240} \mathrm{Pu}$ and ${ }^{238} \mathrm{Pu}$ source term made up of both the liquid effluents from the Marcoule complex and the catchment basin weathering is 123.5 and $34.3 \mathrm{GBq}$, respectively.

The quantities accumulated from 1987 to 1998 in the global Rhône River sedimentary compartment or deposited on the ground during flood periods would then reach about $15 \mathrm{GBq}$ for ${ }^{239+240} \mathrm{Pu}$ and $4 \mathrm{GBq}$ for ${ }^{238} \mathrm{Pu}$. These estimated stocks represent more than $10 \%$ of the global inputs on the studied period. Sedimentary stocks depend on the flood events chronicle and then on the time scale.

These sedimentary stocks represent around 10 times the annual quantities of plutonium isotopes discharged now by the Marcoule plant.

\section{CONCLUSION}

${ }^{239+240} \mathrm{Pu}$ and ${ }^{238} \mathrm{Pu}$ carried by the Rhône River originate in both the weathering of the catchment basin affected by atmospheric fall-out and the controlled liquid effluents discharged by the Marcoule complex set up in the Rhône River valley. Before 1992 industrial wastes represented the major ${ }^{239+240} \mathrm{Pu}$ source term in the Rhône River. At present, annual ${ }^{239+240} \mathrm{Pu}$ inputs related to liquid effluents from the Marcoule complex and from the erosion weathering of the catchment basin are of the same order of magnitude ( 1 $\left.\mathrm{GBq} \mathrm{y}^{-1}\right)$. As to ${ }^{238} \mathrm{Pu}$, its main source term is still linked to the Marcoule fuel reprocessing plant discharges. However the difference between industrial and terrigenous inputs has been reduced by a factor 50 . 
Over the 1987-1998 periods, our results have shown that the decrease in ${ }^{239+240} \mathrm{Pu}$ and ${ }^{238} \mathrm{Pu}$ activities at the lower course of the Rhône River has been proportional to the decrease in Marcoule liquid releases, apart from flood conditions. Flood events generate an increase in plutonium activities partly due to the remobilisation of sediment beds. This delayed secondary source of plutonium may contribute up to $40 \%$ in the plutonium exported to the Mediterranean Sea during floods events.

Mass balances estimated over the 1987-1998 period show that the accumulated activities in the overall Rhône River sedimentary compartment or deposited on the ground during floods are about $15 \mathrm{GBq}$ for ${ }^{239+240} \mathrm{Pu}$ and $4 \mathrm{GBq}$ for ${ }^{238} \mathrm{Pu}$. At the moment, this stock would represent the main ${ }^{239+240} \mathrm{Pu}$ source term in the Rhône River catchment basin, in so far as terrigenous and industrial inputs are of about $1 \mathrm{GBq} . \mathrm{y}^{-1}$ each. Such a sedimentary storage process probably applies to all the radionuclides or to any other contaminant that shows an affinity for particles carried by the River.

\section{References}

[1] Blanc J.J., Sédimentation des marges continentales actuelles et anciennes, Masson Ed. 259 p. (1982).* [2] Badie C., Burollet P.F., Femex F., Triat-Laval H., Essai de bilan de la sédimentation devant l'embouchure du Grand Rhône, Ra Comm. Int. Mer Méditerrannée, 28, 4, 207-208 (1983).

[3] Probst J.L., Géochimie et hydrologie de l'érosion continentale. Mécanismes, bilan global actuel et fluctuations au cours des 500 derniers millions d'années, Mémoire $n^{\circ} 94$, Ed. Institut de Géologie, Université Louis Pasteur de Strasbourg, CNRS, ISSN 0302-2684 (1992).

[4] Bellaiche G, Mart Y, Morphostructure, growth patterns, and tectonic control of the Rhône and Nile deep-sea fans: a comparison, AAPG Bull., 79, 2, 259-284 (1995).

[5] Etchevers P., Golaz C. and Habets F., Simulation of the water budget and the river flows of the Rhône basin from 1981 to 1994 (2001).

[6] Charmasson S., Cycle du combustible nucléaire et milieu marin - Devenir des effluents rhodaniens en Méditerranée et des déchets immergés en Atlantique Nord-Est. Thèse d'Etat, Université Aix-Marseille II, 359 p. (1998).

[7] Vives i Battle J., Speciation and bioavailability of plutonium and americium in the Irish Sea and other marine ecosystems, Thesis, University College Dublin, 347 p. (1993).

[8] Goutelard F., Calmet D. and Thomas S., Determination of Pu isotopes at trace levels in environmental samples: radioisotopes and trace elements evolution during the radiochemical method. Comparison of three radiochemical protocols, Environmental radiochemical analysis ED by G.W.A. Newton, RS.C VIIIth International Symposium on Environmental Radiochemical Analysis, Blackpool, U.K., 23 - 26 September 1998, 97-110 (1999).

[9] Eyrolle F., Goutelard F. and Calmet D., Pu-239+240 and Pu-238 distribution among dissolved, colloidal and particulate phases in the Rhone River waters (France), Proceedings of an International Symposium on Marine Pollution held in Monaco, 5-9 October 1998, organized by LAEA, July 1999, 466467 (1999).

[10] Eyrolle F. and Charmasson S., Significance of colloids in the transport of artificial radionuclides from the Rhone river towards the Gulf of Lion (Mediterranean Sea), Oceanologica Acta, Submitted (2001).

[11] Noël M.H., Le plutonium traceur du transfert et de l'accumulation des apports particulaires du Rhône en Méditerranée Nord Occidentale, Thèse de l'Université Pari XII- Val de Marne, 256 p. (1996).

[12] COGEMA, Compte Rendu Technique annuel, Contrôle des rejets du Site, COGEMA Marcoule.

[13] Thomas A. J., Input of artificial radionuclides to the Gulf of Lions and tracing the Rhône influence in marine surface sediments, Deep-Sea Research, 44, 3-4, 577-595 (1996).

[14] Duffa C., Répartition du plutonium et de l'américium dans l'environnement de la basse vallée du Rhône, Thèse de l'Université d'Aix Marseille III, 179 p. (2001). 